\title{
ESTADO DO CONHECIMENTO SOBRE HISTÓRIA DA ALIMENTAÇÃO INDÍGENA NO BRASIL
}

\author{
State of Knowledge on History of Indigenous \\ Food in Brazil
}

\author{
Tamiris Maia Gonçalves Pereira ${ }^{1}$ \\ Sônia Maria de Magalhães ${ }^{2}$ \\ Elias Nazareno ${ }^{3}$
}

\begin{abstract}
RESUMO
A presente pesquisa contextualiza as abordagens recentes desenvolvidas no âmbito da História da Alimentação, com foco na alimentação indígena. Se anteriormente, até a década de 1950, as pesquisas sobre alimentação eram marcadas por abordagens folclóricas e econômicas, os estudos posteriores sobre a temática trouxeram novas perspectivas. Houve no Brasil o impulsionamento das produções que privilegiaram questões relacionadas à identidade, aos hábitos, à saúde e ao consumo. Propomos, então, uma descrição e análise dos livros, dissertações e teses que privilegiaram a alimentação indígena no Brasil e que permitem a percepção dessa mudança de enfoque. De antemão, afirmamos que a alimentação se tornou alvo de novos questionamentos nas últimas décadas. Com as preocupações voltadas para as políticas ambientais, que buscam implementar a sustentabilidade no manejo do ambiente diante dos novos problemas ecológicos; com os discursos sobre o saudável nutricional e sobre as transformações ocorridas a partir das novas relações entre campo e cidade, a comida permitiu que discussões caminhassem para além das paredes das universidades e instituições acadêmicas, abrindo possibilidades de investigações que abrangessem também os povos indígenas.
\end{abstract}

1 Bacharel em Arqueologia pela Pontifícia Universidade Católica de Goiás, Mestre em História pela Pontifícia Universidade Católica de Goiás e Doutoranda em História pela Universidade Federal de Goiás UFG. E-mail: tamirismaia_19@ hotmail.com.

2 Professor Associado I da Faculdade de História da Universidade Federal de Goiás - UFG, Goiânia, Goiás - Brasil. E-mail: soniademagalhaes@yahoo.com.br.

3 Professor Associado I da Faculdade de História e do Curso de Educação Intercultural da Universidade Federal de Goiás - UFG, Goiânia, Goiás - Brasil. E-mail: eliasna@ hotmail.com. 
PEREIRA, T. M. G., MAGALHÃES, S. M. e NAZARENO E. Estado do Conhecimento sobre História...

Palavras-chave: Estado do conhecimento; História da alimentação; Alimentação indígena.

\begin{abstract}
The present research contextualizes the recent approaches developed in the History of Food, focusing on indigenous food. If previously, until the 1950 s, research on food was marked by folk and economic approaches, later studies on the subject brought new perspectives. There was in Brazil the boost of productions that privileged issues related to identity, habits, health and consumption. We propose, therefore, a description and analysis of the books, dissertations and theses that privilege Indian food in Brazil, which allow the perception of this change of focus. In advance we say that food has become the target of new questions. Concerns about environmental policies, which seek to implement sustainability in environmental management in the face of new ecological problems; with the discourses about the nutritional healthy and about the transformations occurring from the new relations between countryside and city; the food allowed discussions to move beyond the walls of universities and academic institutions, opening up possibilities for investigations that could also cover indigenous people.
\end{abstract}

Keywords: State-of-the-art knowledge; History of food; Indigenous food.

\title{
INTRODUÇÃO
}

Este estudo sobre o tema da alimentação corresponde ao chamado "Estado da Arte" ou "Estado do conhecimento" (FERREIRA, 2002), também denominado de "Pesquisas que estudam pesquisas" (SLONGO, 2004), a ser desenvolvido sobre alimentação indígena ${ }^{4 *}$. O trabalho buscará demonstrar o estado atingido pelo conhecimento nas áreas que investigam a alimentação indígena no Brasil.

De acordo com Ferreira (2002, p. 258), essas pesquisas são:

4* A presente pesquisa é financiada pela Coordenação de Aperfeiçoamento de Pessoal de Nível Superior - CAPES. 
Definidas como de caráter bibliográfico, elas parecem trazer em comum o desafio de mapear e de discutir uma certa produção acadêmica em diferentes campos do conhecimento, tentando responder que aspectos e dimensões vêm sendo destacados e privilegiados em diferentes épocas e lugares, de que formas e em que condições têm sido produzidas certas dissertações de mestrado, teses de doutorado, publicações em periódicos e comunicações em anais de congressos e de seminários. Também são reconhecidas por realizarem uma metodologia de caráter inventariante e descritivo da produção acadêmica e científica sobre o tema que busca investigar, à luz de categorias e facetas que se caracterizam enquanto tais em cada trabalho e no conjunto deles, sob os quais o fenômeno passa a ser analisado.

Esta análise balizará o desenvolvimento da pesquisa, ampliando e reunindo dados para posteriores trabalhos. Em ordem cronológica, descrevemos os documentos (livros, manuais, enciclopédias, artigos, dissertações e teses) que tratam sobre a história da alimentação no Brasil, com o intuito de compreender como chegam aos dias atuais os documentos que abordam a alimentação indígena. Não apresentamos dados e fontes relacionadas à alimentação africana ou afro-brasileira, pois o nosso intuito foi dar destaque à alimentação indígena, que em muitos contextos continua desconhecida, além de subvalorizada e subalternizada.

Iniciamos as descrições a partir de um panorama documental sobre o início dos estudos da História da Alimentação, entre as décadas de 1930 a 1960 no Brasil, quando as obras consideradas "clássicas" são apresentadas pela academia. Apresentamos também algumas obras produzidas da década de 1960 a 1990, momento no qual a alimentação nacional e regional foi amplamente estudada, havendo no início dos anos 1990 maior ênfase em estudos relacionados à alimentação de povos subalternizados, como os indígenas, passando a ser temática central de muitos estudos. 


\section{MARCOS TEÓRICOS NA HISTÓRIA DA ALIMENTAÇÃO}

No início do século XX, estudos e abordagens acadêmicas começam a ser produzidos sobre o tema alimentação. Com o surgimento da Escola dos Annales, em 1929, na França, críticas sobre os métodos tradicionais historiográficos começaram a ser formulados, havendo uma busca por novas formas de ver e fazer estudos e descrições, as quais tentavam ampliar e substituir o uso exclusivo de fontes como textos e registros por documentos de todo tipo: imagens, informações orais, cultura material, dados estatísticos, filmes etc. (LE GOFF, 1998). Os pesquisadores começaram a buscar mais análises e interpretações que descrições e se aproximar de outras ciências, tais como a antropologia, psicologia, literatura, linguística e arqueologia. É nesse momento que a História da Alimentação é proposta como temática da análise social, cultural e histórica. Adam Maurizzio, no artigo Histoire de l'alimentation végétale chez l'Homme (1931), foi pioneiro ao tomar evidências arqueológicas para compreender a etnobotânica e a correlação entre homem e flora no passado. Permitiu-nos visibilizar, inclusive, o papel dos fermentados como cruciais na alimentação e exploração de técnicas de preparo das comidas do neolítico.

A História, então, passa a ser "vista por baixo", pois se volta para opiniões e experiências das pessoas comuns, dando visibilidade à história da cultura popular (BURKE, 1992, p. 10). Nesse contexto, Fernand Braudel (Luméville-en-Ornois, 1902 - Cluses, 1985) merece destaque. Ele foi pioneiro ao valorizar os aspectos comuns da vida social, discutindo comportamentos biológicos, geográficos, alimentação, enfermidades, história econômica e social. $\mathrm{O}$ autor inaugura uma série de debates e indagações em torno desses temas nas ciências humanas, trabalhando os comportamentos que integram os gostos, os gestos e as inovações de costumes, influenciados por produtos alimentícios importados de outros continentes. Os resultados foram publicados em "O mediterrâneo e o mundo mediterrânico na época de Felipe II" (1949) e em "Civilização material, economia e capitalismo" (1979). Esses temas continuam a ser debatidos em períodos posteriores. Ao final da década de 1970 e início da década de 1980, as obras de outros autores franceses como Aron (1976), Flandrin (1983) e Bahlou (1983) seguem sustentando aspectos culturais da alimentação (MAGALHÃES, 2004).

Dentre esses autores, Jean Paul Aron destaca-se ao escrever o artigo “A cozinha: um cardápio do século XIX” (1976), no qual se preocupa em 
debater a alimentação utilizando novos olhares e perspectivas lançados sobre a sociedade parisiense. $\mathrm{O}$ autor menciona que havia, no período em que escrevia, uma "ditadura das antinomias operatórias". Afirmava que a História não eliminou a dificuldade de opor as quantidade e qualidade dos trabalhos historiográficos, mantendo o sistema contra o acontecimento e o signo contra o vivido. Portanto, o autor se propõe enfrentar os obstáculos tratando da cozinha. A cozinha seria um "documento" que diz tudo e nada ao mesmo tempo: nada porque nenhuma narrativa é capaz de expressar o que pensavam os cozinheiros, e tudo porque os cozinheiros redigiam a refeição, a sua composição e seu cerimonial como um texto, que não poderia ser separado de seu objeto. Assim, para Aron, a história culinária não usa vestimenta erudita como os documentos históricos, ela está viva e, portanto, se faz um documento total.

Outro autor que merece notoriedade é Joëlle Bahlou, que, no artigo Nourritures de l'altérité: le double langage des Juifs algériens en France (1983), analisou a alimentação, o comportamento e demais aspectos culturais dos judeus da Argélia instalados na França na década de 1980. Ele produz esse artigo respondendo o convite de Claude Lévi-Strauss, que sugeriu "descobrir os casos individuais de como a cozinha em uma sociedade é uma linguagem em que, inconscientemente, traduz suas estruturas" (BAHLOU, 1983, p. 325). Foi em Mary Douglas (1971), na obra De la souillure, que Bahlou encontrou a importância da fonte bíblica para as suas análises sobre pureza animal; em Jean Soler (1973) a "semiótica" da comida judaica; e em Francis Martens (1977) a proibição da mistura de carne com leite.

Bahlou, utilizando-se da analogia feita por Lévi-Strauss entre cozinha e linguagem, demonstra como a tradição alimentar judaicomaghrebiana se junta aos códigos da sociedade francesa, de maneira a implementar ao mesmo tempo distinção e alteridade. O autor menciona a diferenciação entre os alimentos que são consumidos durante os feriados judaicos e aqueles consumidos nos menus cotidianos. Ela afirma que são as práticas ordenadas em um código social de distinção que fazem o lugar de reafirmação diária das "condições de existência" do grupo, na sociedade majoritária. É por meio do menu e da cozinha que Bahlou traz a análise histórica social. 
Apesar de dirigirem seus olhares para o outro, um outro nunca visto, esses pesquisadores falam por si, dando visibilidade, mas não voz, aos "marginalizados". . Isso ainda deixa lacunas que mais tarde serão abordadas por outros pesquisadores, como aqueles que tratam sobre as influências das políticas de globalização da alimentação na atualidade.

Se as abordagens acerca da História da Alimentação têm início na disciplina de Arqueologia com as análises paleobotânicas e na História por meio dos Annales, na disciplina de Antropologia ela ganha impulso com os trabalhos etnográficos e obras publicadas sobre povos nativos de países não europeus. As primeiras abordagens sobre o tema começam a se consolidar na Europa na década de 1940, ganhando maior impulso com Audrey Richards (1939), sob uma perspectiva funcionalista. Ao mesmo tempo, nos Estados Unidos, trabalhos sobre alimentação são desenvolvidos por Margaret Mead (1932; 1935), mas sob uma perspectiva culturalista, na qual a pesquisadora buscava identificar as necessidades dos grupos sociais, levantando seus hábitos alimentares.

No Brasil, entre os anos 1930 e 1940, algumas concepções relacionadas às posturas metodológicas nas produções científicas começaram a se ligar às análises estruturalistas. Com a entrada das informações e perspectivas de sociólogos e etnógrafos europeus e norte-americanos como Lévi-Strauss e Audrey Richard, e seus novos vieses voltados também às pesquisas de campo, é colocada em evidência a importância dos estudos da alimentação na construção da "civilização brasileira".

Os trabalhos sobre História da Alimentação no Brasil começam a despontar nesse período e muitos deles são considerados clássicos na atualidade. Eles apresentam dados que contribuíram e contribuem até hoje para a construção e alicerce de ideias sobre as práticas, hábitos e identidades

5 Jim Sharpe (1992) nos convida a pensar nas discussões e debates que circulam em relação à "história vista de baixo". Segundo o autor, a historiografia das "pessoas comuns", "das massas", "do povo", mudou a forma de se fazer História. Ela auxiliou na construção de identidades consideradas inferiores, ao mesmo tempo em que criticou e redefiniu a corrente principal da história "de cima", permitindo conhecer mais sobre o passado sob outras perspectivas. Mesmo tendo um caráter "subversivo", Sharpe nos lembra que a "história vista de baixo" implica que há algo acima e, portanto, deve ser relacionada, pois caso contrário corremos o risco de fragmentação e redução da História. O autor também observa que apesar de haver muitos estudos sobre os camponeses, operários, etc., existem poucos materiais que possam ser considerados testemunho diretos das próprias "pessoas comuns". Mesmo com as tentativas de preencher essas lacunas (documentos jurídicos, testamentos, registros paroquiais, transações de terras, por exemplo), as "experiências" e o "mundo mental" das pessoas do passado continuam sendo desafios aos historiadores. 
alimentares no país. Além disso, abrem espaço para compreensão da importância desse tipo de estudo na ocupação do território brasileiro, trajetória política e econômica nacional.

Uma das ideias mais presentes nesses clássicos está relacionada à construção da alimentação nacional. Ela é a concepção de que a mistura interétnica (europeus, indígenas e africanos) providenciou o conjunto de conhecimentos alimentares capaz de consolidar as preferências e hábitos na mesa brasileira. Estas teriam sido iniciadas durante o período colonial e continuaram durante o tráfico negreiro e posteriormente a ele. Momentos em que as comidas, modos de fazer, servir e os gostos são concebidos nas cozinhas das aldeias, nas senzalas, nas casas rurais e nas casas e ambientes urbanos, dando origem às "comidas brasileiras" (FREYRE, 2003).

A ideia de três matrizes étnicas é recorrente e permanece em muitas publicações atuais. Ela foi trazida inicialmente por Capistrano de Abreu, em "Capítulos de História Colonial" (1907) e disseminada largamente por Gilberto Freyre, em "Casa Grande e Senzala" (1933). Posteriormente, o conceito é visto em "Monções" (1945) e "Caminhos e Fronteiras" (1956), escrito por Sérgio Buarque de Holanda. Em seguida, é observado em "História Econômica do Brasil" de Caio Prado Junior (1945) e em "História da alimentação no Brasil" (1968) e "Antologia da alimentação no Brasil" (1977), de Luís da Câmara Cascudo. O indígena e a alimentação aparecem nessas obras normalmente nos primeiros capítulos, destinados a mostrar as origens "primitivas" ou "primeiras" da alimentação 6 .

6 Podemos citar, ainda, outras importantes obras para a História da Alimentação brasileira, tais como: "Comida e Sociedade: uma História da alimentação" (2003), de Henrique Soares Carneiro; "História da alimentação no Paraná" (1995); os artigos "Por uma história da alimentação" (1997) e "A alimentação e seu lugar na história: os tempos da memória gustativa" (2005), de Carlos Roberto Antunes dos Santos; "A história da alimentação: balizas historiográficas" (1997), artigo de Ulpiano Toledo Bezerra Meneses e Henrique Soares Carneiro; "Doces de ovos, doces de freiras: a doçaria dos conventos portugueses no livro de receitas da irmã Maria Leocádia do Monte do Carmo (1729)" (2002); "Aguardente de cana e outras aguardentes: por uma história da produção e do consumo de licores na América portuguesa" (2005); "Alimentação, saúde e sociabilidade: a arte de conservar e confeitar os frutos (século XV-XVIII)" (2005); "Tabernas e botequins: cotidiano e sociabilidade no Rio de Janeiro (1808-1821)" (2012); "Alimentação e cultura material no Rio de Janeiro dos Vice-reis" (2016), de Leila Mezan Algranti; “Apício: história da incorporação de um livro de cozinha da Alta Idade Média (século VIII ao IX)" (2010), de Wanessa Asfora Nadler; "A mesa de Mariana: Produção e consumo de alimentos em Minas Gerais (1750-1850)" (2018), de Sônia Maria de Magalhães; "A cultura alimentar paulista: uma civilização do milho? (1650-1750)" (2012), dissertação de Rafaela Basso. 
PEREIRA, T. M. G., MAGALHÃES, S. M. e NAZARENO E. Estado do Conhecimento sobre História...

Entre várias outras obras desses mesmos autores e de outros pesquisadores que não citamos, podemos destacar que os títulos que tratam da ideia de três matrizes étnicas foram de grande relevância para os estudiosos da área, mas em nenhuma delas os indígenas aparecem em primeiro plano. Em períodos posteriores, da década de 1970 até a década de 1990, os indígenas deixam de ser mencionados em muitas obras nacionais. Se antes compunham os primeiros capítulos, passam a não existir nas publicações seguintes. A conjuntura sociopolítica desenvolvida no Brasil com a ditadura militar proporcionou muitas mudanças.

Vários conflitos entre seringueiros, posseiros, militares e indígenas surgiram no período. Muitos não indígenas se embrenharam em meio às "matas virgens", a fim de ocupar terras com a atividade agropecuária e mineradora. Eles foram assentidos pelo Governo Federal brasileiro, que buscava construir obras faraônicas, militarizar e escolarizar os indígenas, a fim de integrá-los à sociedade brasileira, representado oficialmente pelo SPI (Serviço de Proteção ao Índio), atual FUNAI (Fundação Nacional do Índio). Tal contato provocou epidemias que causaram a morte de vários povos, sem acesso a remédios ou qualquer órgão que garantisse seu bem-estar e segurança. Os indígenas foram esquecidos e continuaram destinados a sobreviver resistindo e fugindo das ações dos não indígenas. Com a Constituição Brasileira de 1988, o direito às terras, saúde e educação passam a ser lei e os povos indígenas são assegurados em seus territórios, apesar de conflitos e violências. Mas a luta pela demarcação de suas terras ainda permanece até os dias atuais.

O desenvolvimento de estudos acadêmicos voltados às temáticas da fome, desnutrição e abastecimento surgem, e, em contrapartida, o enfoque nos temas relacionados à etnicidade diminuem. Projetos de pesquisa foram financiados pelo Governo Federal militar durante a década de 1970, a fim de realizar estudos sobre o abastecimento nacional. Tais questões contribuíram para o adormecimento dos estudos relacionados à alimentação dos povos indígenas. Esta é uma problemática que desenvolveremos à frente. 


\section{ESCRITOS SOBRE ALIMENTAÇÃO INDÍGENA NO BRASIL}

Capistrano de Abreu, em "Capítulos de História Colonial" (1907), enfatiza a colonização portuguesa sob o viés sociopolítico e a formação do povo e território brasileiros entre os séculos XVI e XIX. O autor considera em sua obra os fatores domínio e exploração da terra e dos nativos como conflitivos, mas sem deixar de conferir importância para a superioridade colonizadora europeia. A alimentação é tratada com informações históricas importantes a partir desse viés de miscigenação, porém de maneira secundária. Baseando-se em fontes como os relatos de jesuítas, franciscanos, capuchinhos e colonos que se instalaram no Brasil, como padre Manoel da Nóbrega, padre Antônio Vieira, Fernão Cardim e Gabriel Soares de Sousa, o autor realiza descrições sobre a forma como ocorreu a fixação europeia e a exploração das terras brasileiras. Ele descreve também a alimentação indígena, que tinha como base alimentos oriundos de uma agricultura "incipiente", da caça e da pesca, entendendo que essa alimentação era "inferior" à europeia pela ausência da carne de víveres domésticos e por isso pobre em seu teor nutricional.

[...] De caça e principalmente de pesca era composta sua alimentação animal. Possuia agricultura incipiente, de mandioca, de milho, de varias fructas. Como eram-lhe desconhecidos os metaes, o fogo, produzido pelo attrito, fazia quasi todos os officios do ferro. A plantação e colheita, a cozinha, a louça, as bebidas fermentadas competiam às mulheres; encarregavam-se os homens das derrubadas, das pescarias, das caçadas e da guerra (ABREU, 1907, p. 10).

O autor menciona também que o nomadismo indígena era decorrente da exaustão do solo do território de ocupação pelos grupos ${ }^{7}$. Capistrano

7 Acerca do suposto nomadismo dos povos indígenas, Pin (2014, p. 130 apud Fonseca, 1846) afirma em relação aos povos Iny, Karajá e Javaé que: “[...] há evidências claras de que os Javaé sempre 
constrói a figura do indígena no processo de formação brasileiro como aquele que muito auxiliou na ocupação territorial e sem o qual não seria possível tal acontecimento. Diante de rios, matas, animais peçonhentos e diversos outros povos indígenas desconhecidos, Capistrano afirma que os europeus eram incapazes de se desvencilhar dos perigos e sucumbiam facilmente. Outro ponto que não deixamos de notar na obra é a descrição da alimentação cotidiana, presente especificamente nas casas grandes e abastadas do século XVII, próximas ao litoral. O índio escravizado foi "protagonista" $\mathrm{e}$ mantenedor no Brasil da alimentação cotidiana, assim como do vestuário dos europeus. Eram eles que forneciam o peixe (de água doce ou salgada), mariscos (apanhados no mangue) ou caça. Criavam ovelhas, cabritos, porcos, e ainda, eram encarregados de trocar as pipas de vinho e azeite nas vilas. Nesse momento, a alimentação europeia é praticamente toda indígena, o que culminou na incorporação de muitos alimentos à dieta europeia no Brasil. $\mathrm{O}$ uso da mandioca na preparação de beijus e tucupi, o consumo de peixes e tartarugas, o uso do milho com a produção de pamonha, pipoca, canjica, além de produtos florestais como as castanhas e ervas foram todas oriundas do conhecimento e produção indígena.

A casa da gente rica representava uma economia autônoma: o nec est quodputes illum quidquam emere, omnia domi nascuntur, de Petronio, não podia ser praticado ao pé da lettra, mas correspondia até certo ponto à realidade. Para os escravos fiava-se e tecia-se a roupa; a roupa da familia era feita no meio d'ella; da alimentação, fornecida por peixe de água doce ou salgada, mariscos apanhados nos' mangues ou caça, estavam encarregados os escravos; a criação miúda de voláteis, ovelhas, cabritos e porcos evitava as sorpresas de hospedes da ultima hora: não havia açougues ou mercados: as casas dos ricos (ainda que seja á custa alheia, pois muitos devem o que têm) andam providas de todo o necessário, pois têm escravos pescadores e caçadores, que lhes trazem a carne e o peixe, pipas de

praticaram a agricultura. Por exemplo, quando em 1775, Antonio Pinto da Fonseca esteve entre os Karajá e recebeu os Javaé em seu acampamento provisório, relatou que os dois povos tinham roças e destacou inclusive que por vezes deixavam de ir até elas por temer os ataques do povo "Chavante" que "[...] no tempo da secca costumava passar o rio a nado e iam arranchar-se nas roças.” (FONSECA, 1846, p. 385). 
vinho e azeite que compram por junto, nas villas muitas vezes se não acha isto de venda (ABREU, 1907, p. 69).

A construção de uma alimentação considerada brasileira, tal como concebemos hoje, permite pensar que o colonizador tanto influenciou quanto foi influenciado pela culinária, pelo gosto, pelas receitas, pelos modos de fazer e pelos conhecimentos nativos. As terras brasileiras e o ambiente foram modelados e modelaram os homens que aqui pisaram durante séculos.

Capistrano (1907) deu o pontapé inicial para o que mais tarde seria usado como fonte na obra, já mencionada, de Gilberto Freyre, "Casa Grande e Senzala" (1933). Nessa obra, a ótica da miscigenação étnica permanece, assim como a imagem da construção de uma sociedade hierárquica, associada ao patriarcalismo escravocrata, em que senhores, escravos e filhos da miscigenação garantiriam a moradia, alimentação, segurança, sistema de crenças cristãs através da língua portuguesa. A manutenção da unidade, no entanto, não se reproduziu em outros países da América espanhola e inglesa. Como um dos mais fortes elementos unificadores coloniais estaria a Língua Portuguesa, mediada pelo catecismo jesuíta com a transição da Língua Tupi para a portuguesa através da Língua $\mathrm{Geral}^{8}$. Outro forte elemento unificador mencionado pelo autor foi a religião cristã católica, instalada também por mãos de jesuítas e franciscanos durante o projeto colonial. Além da língua, Gilberto Freyre (1933) descreve a maneira pela qual vários costumes, perante a miscigenação, foram se entrelaçando e reduzindo distâncias entre elementos culturais diversos e muitas vezes antagônicos: alimentação, saberes relacionados à saúde, ao meio-ambiente, além da construção de festividades, construção do medo e crenças no sobrenatural.

Quanto ao indígena, o autor afirma que as mulheres foram as responsáveis pela introdução dos conhecimentos e usos de diversos alimentos, drogas e medicamentos, utensílios, criação das crianças e higiene

8 A Língua Geral, de que nos fala Freyre (1933) e outros autores, é uma nomenclatura genérica para designar as línguas faladas na América do Sul quando houve o contato entre europeus e povos indígenas. Aryon Rodrigues (1986) utiliza o termo para designar as línguas que se constituíram e foram utilizadas, do século XVI até o XIX (LAGORIO, 2014; FREIRE, 2003). 
PEREIRA, T. M. G., MAGALHÃES, S. M. e NAZARENO E. Estado do Conhecimento sobre História...

(banhos). Foram as indígenas que "ensinaram" o processo de coivara, o conhecimento sobre o cultivo de raízes e sementes. Na agricultura, ensinaram a plantar mandioca, cará, inhame, milho, jerimum, amendoim e mamão. "Casadas" ou escravizadas pelos portugueses, construíram um jeito mestiço de ensinar sobre o ambiente (FREYRE, 2003). Os homens indígenas foram os guias territoriais, mão de obra escrava que muito influenciou a navegação fluvial e o domínio mercantil no interior do território brasileiro. Com a miscigenação étnica tratada como grande instrumento sociopolítico colonial, Gilberto Freyre (1933) desconstrói a imagem do português herói e grande conquistador. A sua importância está em conhecer a dominação através das misturas étnicas como forma de "amolecer" os embates duros e diretos entre culturas distintas.

Freyre (2003) destaca a farinha de mandioca, adotada pelos colonos no lugar do pão de trigo, por ser considerada fresca, sadia, proveitosa e de fácil digestão. De acordo com o autor, foi nas cozinhas das casas-grandes que os vários quitutes feitos de mandioca "perderam o ranço de origem para se tornarem abrasileirados" (FREYRE, 2003, p. 191-192). Além da mandioca, a batata-doce, os pinhões, o cacau, o amendoim, o mamão, o araçá e o caju, usados de forma medicinal e culinária, se tornam matéria-prima para a constituição de uma culinária brasileira.

Seis anos após publicar "Casa Grande e Senzala", um dos livros de maior destaque do autor, Freyre produziu "Açúcar: uma sociologia do doce", com receitas de bolos e doces do Nordeste do Brasil (1939). Nessa obra, Freyre descreve e analisa a história do açúcar no Brasil, a importância do doce e sua construção no paladar brasileiro.

Envolvido no "Manifesto Regionalista de 1926", Freyre se empenha na valorização da tradição culinária de artes regionais, como a doçaria. Esse empenho foi duramente criticado por sociólogos e historiadores do mesmo período, por ser considerado na época como um estudo menor, que estava sob o interesse de mulheres, um tema muito feminino que não era digno de uma sociologia. "Não se compreendia que intelectuais varonis cuidassem de matéria tão feminina como guisados e doces, rendas e bordados" (FREYRE, 1997, p. 32). Influenciado por perspectivas do Movimento Modernista, da Antropologia e Sociologia, que nesse período buscavam novos temas que pudessem trazer novas construções sobre o viés cultural, Freyre produz o livro "Açúcar: uma sociologia do doce" (1939). A obra reúne diversas receitas de bolos, doces e sorvetes coletados de famílias de Pernambuco e de outros estados no nordeste brasileiro, que são chamados de receitas tradicionais. 
Em "Açúcar", Freyre faz pouca menção aos indígenas, trazendo-os para história como povos que ensinaram os europeus a obter alimentos, principalmente a escolher frutas e outros frutos, que associados ao açúcar da cana-de-açúcar virariam doces e outras sobremesas, por meio dos modos de preparo português: "Frutas como a pitanga, maracujá, groselha, coração-daíndia, carambola, goiaba, guajiru, cajá, araçá, mangaba, imbu, mamão, jabuticaba e sapoti tiveram sua fase de esplendor na mesa patriarcal" (FREYRE, 1997, p. 68).

Além das frutas e frutos da terra, Freyre (1939) demonstra em "Açúcar: uma sociologia do doce" como algumas receitas de origem indígena permaneceram entre aquelas aceitas pelo paladar português. Ele cita autores como Manuel Querino, Araújo Lima, Leandro Tocantins e Nina Rodrigues, que documentaram traços "curiosos" sobre as receitas de origem indígena, como por exemplo, receitas de guisados e assados de lagarto, paca e capivara.

Seis anos mais tarde, Sérgio Buarque de Holanda produz a obra "Monções" (1945), na qual trabalha as expansões paulistas por vias fluviais, saídas de São Paulo rumo a Cuiabá. Monções é a denominação que o autor dá às levas de povoamento e de abertura de comércio que rumaram em direção oeste e centro do Brasil, do século XVI ao início do XIX. Ele destina maior atenção aos séculos XVII e XVIII, quando eram mais numerosas as bandeiras paulistas que buscavam ouro e outros metais preciosos.

Nessa obra, a alimentação também é trabalhada, porém de maneira secundária, uma vez que a prioridade está em documentar os caminhos, obstáculos, empecilhos e articulações "adaptativas" da navegação e ocupação de regiões antes habitadas e conhecidas somente por indígenas. Mesmo secundária na obra, a alimentação é colocada como essencial para a ocupação luso-brasileira, pois foi por meio das técnicas de pesca, caça e coleta de frutos, aprendidas em grande parte com os indígenas, que foi possível a ocupação. A importância do indígena é enfatizada pelo autor em todo processo de ocupação das bandeiras. Holanda (1945) dá continuidade à construção da figura do brasileiro miscigenado, porém com alguma diferença das obras anteriores. Ele trata a figura indígena como principal conhecedora e negociadora nas relações territoriais, mesmo sob domínio português. A mistura de negros, índios e brancos na construção da alimentação brasileira se torna, na obra, parte do processo de negociação dos agentes sociais no tempo.

Josué de Castro, em 1946, publica a obra "Geografia da Fome" e cinco anos mais tarde lança "Geopolítica da fome" (1951). Tais livros 
PEREIRA, T. M. G., MAGALHÃES, S. M. e NAZARENO E. Estado do Conhecimento sobre História...

expunham o problema da fome no Brasil, analisando os seus efeitos e inaugurando as buscas por investigações nutricionais alimentares. Os escritos do autor, e principalmente sua atuação, formularam quadros importantes de políticas sociais de combate à fome no Brasil, como a implementação de restaurantes populares e políticas de educação alimentar. Josué de Castro evidenciou preconceitos sociais e raciais relacionados aos trabalhadores brasileiros, permitindo mudar a forma de ver "preguiça" e "indolência" pelos empregadores da camada operária. Muitos donos de fábricas e de outros empreendimentos exigiam longas jornadas de trabalho com baixa remuneração, fazendo com que os valores destinados à compra de alimentos fossem mínimos, gerando a fome. Os indígenas aparecem em suas obras como grupo formador da cultura e da herança biológica que constitui o homem brasileiro. Josué menciona que a alimentação indígena é rica em vitaminas, favorecidas pela diversidade vegetal e animal, tendo nas técnicas e processamento dos alimentos a principal forma de prática entre os sertanejos, herdeiros e descendentes dos indígenas.

Em 1954, Antonio Candido defende a tese "Os parceiros do Rio Bonito", publicada em formato de livro no ano de 1964. Nessa obra, o autor se propõe investigar como se dá a obtenção dos meios de vida do caipira, no modo de vida do tipo fechado, com base na economia de subsistência. Ele se utiliza das perspectivas materialistas de Marx para realizar suas análises.

[...] Marx abriu efetivamente horizontes mais largos para se compreender a solidariedade profunda do mundo físico e da cultura humana, encarados, por ele, à luz do desenvolvimento histórico [...]. Baseado aí pôde determinar uma posição fecunda para compreender a vida social a partir da satisfação das necessidades, mostrando, de um lado, que a obtenção dos meios de subsistência é cumulativa e relativa ao equipamento técnico; de outro, que ela não pode ser considerada apenas do ângulo natural, como operação para satisfazer o organismo, mas deve ser também encarada do ângulo social, como forma organizada de atividade (CANDIDO, 2010, p. 28-29).

Candido se preocupa em trazer análises que não sejam estáticas ou idealizadas, e sim que levem em consideração as mudanças ao longo do tempo. Para realizar suas análises, elege a alimentação e a dieta como 
principal foco de seu trabalho. $\mathrm{O}$ autor menciona dados documentais e descrições obtidas em trabalho de campo na região de Bofete, São Paulo, associadas às suas análises sobre os modos de subsistência de famílias rurais no período estudado. Candido trabalha o modo de produção e o consumo dos alimentos plantados (feijão, milho, mandioca e arroz), o consumo de alimentos e outros bens obtidos pelo comércio (sal, cachaça, pólvora, roupas, panelas e talheres, enxada e outros instrumentos agrícolas), a produção do açúcar, da garapa e da rapadura, a criação de animais e a atividade de caça e coleta para a complementação da dieta.

Dentre essas análises, chama atenção a maneira como ele representa o indígena, como aquele que fornece os meios de subsistência e as matériasprimas para o consumo, porém, esses meios e matérias não são transformadas ao seu modo. Há hegemonia e predominância nos modos de produção europeus com o uso dos ingredientes indígenas.

O feijão, o milho e a mandioca, plantas indígenas, constituem, pois, o que se poderia chamar triângulo básico da alimentação caipira, alterado mais tarde com a substituição da última pelo arroz. No entanto, a maioria dos modos de prepara-los não veio do índio: constituem adaptação de técnicas culinárias portuguesas, ou desenvolvimentos próprios do país. Sob este ponto de vista, apenas a mandioca se transmitiu integralmente, tanto a doce, o aipim dos nortistas (Manihot dulcis Pax), ingerida sem maior transformação, quanto a amarga (Maniot utilíssima Pohl), de que se extraía farinha, pelos mesmos processos com que a obtinham os naturais do país, embora com técnicas frequentemente aperfeiçoadas (CANDIDO, 2010, p. 64-65).

Candido afirma que o feijão, de origem indígena, foi "lusitanizado" em seu modo de preparo, acrescentando-se ao cozer sal, banha e carne de porco. Do milho indígena "lusitanizado", fez-se uma série de comidas, dentre elas: espiga assada ou cozida, pamonha, mingau, bolo, curau, pipoca, quirera, canjica, fubá, biscoitos, bolinhos, broas e farinha. A mandioca trouxe junto com ela a tecnologia material dos indígenas: ralo e tipiti, dando origem também a um complexo material já com a influência lusa que correspondeu aos primeiros utensílios para uso cotidiano: peneiras, pilões de mão e de pé, 
PEREIRA, T. M. G., MAGALHÃES, S. M. e NAZARENO E. Estado do Conhecimento sobre História...

monjolos, moinhos d'água, fornos de barro e formas. Além desses importantes alimentos, as abóboras e batatas eram fontes substanciais alimentares: batata-doce, cará e mangarito.

$\mathrm{O}$ sal foi um dos condimentos que mais levou os indivíduos a estabelecerem uma relação intergrupal, pois a sua necessidade obrigava a realização de contatos periódicos com as vendas ou centros urbanos. O leite, o trigo e a carne de vaca constituíam alimentos excepcionais na dieta, sendo indicativo de índice de urbanização ou situação social abastada. Mas o que nunca sumiu da dieta do homem rural foi o açúcar, que originava a garapa e a rapadura, e, ainda, a aguardente, mesmo quando esse cultivo minguou. No século XIX, juntou-se a cana, o café. Segundo Candido, essa dieta só se faz viável se houver complemento: caça, pesca e coleta. Coleta de frutos do mato (jabuticabas, maracujás, araticuns, goiabas, jaracatiás, pitangas e bananas), do campo (juá-manso, gravatá, caraguatá e mamão) e palmitos.

Havia e há discriminação acentuada não apenas entre animais comestíveis ou não, mas entre aqueles, uma hierarquia de gosto. Paca, porco-do-mato, tatuetê, teiú, macuco, nhambu constituem de modo geral as iguarias mais prezadas. Nota-se sem dificuldade que a preferência do paladar se norteia pela afinidade das suas carnes com a dos animais domésticos: porco, leitão, frango, galinha - indicando nitidamente o caráter substitutivo da caçaalimento. As carnes de sabor estranho (asco), são rejeitadas ou menosprezadas [...] (CANDIDO, 2010, p. 69).

Candido permite pensar na ideia de dinâmica cultural, mais do que na cristalização e formação de costumes. O que é de grande importância é a forma como ele menciona a preferência ou o menosprezo pelo sabor dos alimentos, que varia em tempo e espaço. A satisfação do paladar segue os padrões existentes em uma sociedade e em sua época.

Quase vinte anos após a publicação de Candido (1964), o livro "Plantar, colher, comer: um estudo sobre o campesinato goiano" (1981), de Carlos Rodrigues Brandão, é divulgado. Inspirado nas análises de Candido, Brandão busca compreender as práticas alimentares da região de Mossâmedes, Goiás, principalmente aquelas dos lavradores, peões, boiadeiros e fazendeiro. Em suas análises, o autor aponta uma íntima relação 
entre práticas econômicas e práticas alimentares ligadas ao trabalho agrícola e pecuário para fins de subsistência dos indivíduos, marcando o sistema e estrutura de produção, o cultivo de alimentos, a circulação de comida e mantimento e o seu consumo pelas famílias camponesas. Apesar de organizar o seu trabalho dentro desses parâmetros de análise, a sua principal contribuição recaiu sobre o "deixar que fale o produtor de subsistência" (BRANDÃO, 1981, p. 11). Brandão apresentou os simbolismos, o desdobramento das ideologias e crenças ligadas à produção, circulação e consumo alimentares, como forma de explicar as representações e comportamento social. Ligado à antropologia cognitiva, faz uma estreita relação entre o meio e o homem em termos de interpretação dos elementos do imaginário que povoam e impulsionam suas ações. Seu trabalho representou um marco para os estudos da agricultura, campesinato e da alimentação, relacionados à perspectiva materialista que liga o homem ao meio social, econômico e simbólico.

Ainda que descreva a região de Mossâmedes como área de antigo aldeamento indígena, Brandão não menciona as influências indígenas na alimentação da população local, uma vez que seus interlocutores não possuíam memória ou identificação com o passado indígena.

[...] o lavrador [...] faz referências ligeiras, e de conhecer limitado, aos indígenas reunidos em séculos passados pelas autoridades portuguesas em dois aldeamentos próximos à antiga capital do Estado - a Cidade de Goiás - e vizinhos entre si: a Aldeia de São José e a Aldeia Maria. Assim, para o lavrador de hoje, as pessoas do passado de sua região - as do começo de um "tempo antigo" vieram atrás das primeiras boiadas e foram os construtores das primeiras fazendas (BRANDÃO, 1981, p. 8-9).

Apesar de não mencionar os indígenas, seu trabalho constituiu um marco nas produções a respeito da alimentação em Goiás.

No ano de 1968, quatro anos após a produção de "O cru e o Cozido" por Lévi-Strauss (1964), trabalhando sob a perspectiva da identidade coletiva, Luís da Câmara Cascudo publica "História da alimentação no Brasil". O autor faz uma reunião de documentos, trabalhos antropológicos e sociológicos que trataram o tema da alimentação, alicerçando a miscigenação 
PEREIRA, T. M. G., MAGALHÃES, S. M. e NAZARENO E. Estado do Conhecimento sobre História...

das três raças como precursoras das bases sociais e culturais da alimentação brasileira. Cascudo desenvolve um capítulo sobre cardápio indígena por meio de elementos constituintes dessa cozinha, trazendo-os como formadores da base alimentar ameríndia brasileira. Os inhames, palmitos, mandioca, milho, bananas, pimentas e outros temperos constituiriam os alimentos básicos de comidas nativas. O fogo, moquém, trempe e forno seriam maneiras de articulação tecnológica indígena para a produção alimentar que os colonizadores europeus teriam imitado por longos séculos, assim como muitos dos alimentos e comidas teriam sido apreciados e adaptados ao paladar dos recém-chegados no Velho Mundo. Câmara Cascudo (2004) constrói a imagem da mulher indígena como a responsável por alimentar a colônia brasileira e mantê-la sadia até pelo menos os meados do século XVII, quando houve a entrada dos africanos no Brasil, mantendo uma cozinha mestiça, limpa e com riqueza em termos de diversidade vegetal.

Nove anos mais tarde, Cascudo organiza a obra "Antologia da alimentação no Brasil" (1977), já tendo "aberto caminhos na sistemática, nos debates e conclusões, tendo manejado material limitado" sobre alimentação em "História da alimentação no Brasil" (1968). Em "Antologia da alimentação no Brasil", o autor busca evocar diversos aspectos da alimentação brasileira sob vários vieses: histórico, etnográfico, literário e social. Seu principal objetivo é tratar sobre "alimentação, e não nutrição" (CASCUDO, 1977, p. 1). Cascudo afirma que as páginas são "velhas e novas, [...] atualizando as antigas e reavivando as recentes no diagrama do paladar brasileiro" (CASCUDO, 1977, p. 1), ou seja, deixa a ideia de movimento, de mudança das receitas, dos saberes e fazeres populares.

Presente no próprio título do livro, a palavra antologia corresponde a uma coletânea de textos diversificados a respeito da alimentação no Brasil, apresentando desde poemas, músicas, receitas, descrições até análises sobre os alimentos, modos de aquisição e preparo. $\mathrm{O}$ autor também se utiliza de textos sobre comportamento social e político relacionados à alimentação nas classes mais abastadas e pobres, nas áreas urbanas - "um ambiente urbano antes do automóvel, da luz elétrica e das rodovias" (CASCUDO, 1977, p. 1) e rural. Entre os autores que contribuíram com a obra estão Pereira Barreto, Artur Ramos, Vinícius de Moraes, Santa Rita Durão, Marcgrave, Debret, Sant-Hilare, Euclides da Cunha, Martius, Bariani Ortêncio e Manuel Querino. Aqui, Cascudo reafirma a ideia de miscigenação e coloca, mais uma vez, a hegemonia dos modos de preparo dos alimentos europeus sobre a dos outros povos de maneira aberta. Ele afirma que "[...] quem faz a comida, tempera ao 
seu paladar. Paladar corresponde ao Timbre, fisionomia da Percepção." (CASCUDO, 1977, p.1). Nessa frase, o autor atesta que foi o sal, o condimento europeu, que temperou o paladar do brasileiro, e o açúcar que adoçou, em substituição ao mel de abelha, de uso indígena e africano.

$\mathrm{O}$ autor não foge muito das representações construídas anteriormente pelos autores que descreveram histórica e sociologicamente a alimentação brasileira. Ele inclusive utiliza-os, como fonte para a construção da sua obra. A atenção dada ao nativo é a de sempre considerá-lo primordial à colonização, colocando este como um indígena uno, sem distinção cultural entre povos e vozes. Os "nativos da terra" teriam um único costume alimentar e uma única cozinha compartilhada?" Essa imagem é amplamente questionada em períodos posteriores e é problematizada nas décadas de 1980 e 1990, quando novas perspectivas voltadas à história cultural, ao póscolonialismo e a perspectiva decolonial ${ }^{10}$ começam a vigorar nas análises.

$\mathrm{Na}$ década de 1980, autores estadunidenses, indianos e caribenhos como Sahlins (1981), Spivak (1990), Bhabha (1994) e Hall (1996), buscaram mostrar como os processos diaspóricos, os preconceitos raciais e socioeconômicos, as torturas e outras ações brutais são legitimadas pelo poder e pelas perspectivas eurocêntricas (PEZZODIPANE, 2013). No âmbito da alimentação, tais perspectivas ganham força na América Latina com as obras de Goody (1982) e de Mintz (1985), que analisam as cozinhas locais, incluído o fator exploração como mercadoria e produto social e simbólico de significação, que muito auxiliou na construção de hierarquias sociais e raciais.

Essas referências se tornaram importantes fontes de estudos para as produções brasileiras na década de 1990. Entretanto, é preciso destacar que as pesquisas sobre povos indígenas, que já eram reduzidas, praticamente somem do cenário nacional. Esse evento se deve provavelmente pela conjuntura

9 Sobre a diversidade de povos e línguas indígenas, Nazareno (2019, p. 301) afirma que no trabalho de catequização e educação empreendido por parte dos jesuítas, um dos aspectos centrais para o êxito que obtiveram foi o domínio de parte das línguas indígenas e sua utilização como instrumento de dominação. Cavalcanti (1999, p. 389) alega que o Brasil contava com cinco milhões de indígenas, falantes de pelo menos 1.300 línguas. Atualmente, restam pouco mais de 170 línguas e algumas delas correm sérios riscos de desaparecimento.

10 Perspectiva decolonial surge como uma teorização Latino-Americana que vem sendo realizada por pensadores como Enrique Dussel, Walter Mignolo e Aníbal Quijano, a fim de mostrar como o colonialismo moderno europeu nas Américas forjou através de elementos ideológicos "o outro", um "outro colonial", que era ao mesmo tempo objeto de seus estudos, e contraponto da imagem do seu lócus de enunciação (CASTRO-GÒMEZ, 2005). 
política, social e econômica ocorrida no Brasil na transição das décadas de 1970 para 1980. Foi um período em que as organizações internacionais, como a UNESCO (Organização das Nações Unidas para a Educação, a Ciência e a Cultura), atuam no Brasil investindo recursos em projetos para a recuperação de patrimônio cultural junto ao SPHAN (Serviço do Patrimônio Histórico e Artístico Nacional), tendo como objetivo alavancar o turismo. Também acontecem estudos voltados à desnutrição e fome de populações marginalizadas. Essa intervenção ocorre em outros países da América, como no México, em que os povos indígenas têm suas comidas alçadas ao status de Patrimônio Alimentar, por um lado e, por outro, são tratados como povos marginalizados e que “"[...] não sabem o que devem comer”" (KATZ, 2013, p. 2) segundo as autoridades do patrimônio cultural. Tal influência internacional levou ao aumento de interesse pelos estudos nas áreas de saúde e turismo, focados na fome, desnutrição e patrimônio cultural nas esferas urbanas, uma vez que os financiamentos públicos internacionais se voltavam a eles. Além disto, o cenário nacional das políticas públicas vão ao encontro das políticas internacionais, pois havia também preocupações com a fome e a desnutrição, por contrariarem o chamado "milagre econômico" durante os "anos de chumbo" (1969-1973), havendo investimentos voltados aos programas de Diagnóstico Nacional das Despesas Familiares (FIBGE, 1974/1975) e do Grupo de Ciências Sociais do Estado Nacional de Despesas Familiares (Fineep/INAN/IBGE) por parte do governo, vinculados à Universidade de Brasília e ao Museu Nacional (CANESQUI, 2005).

Nesse momento, os indígenas são classificados dentro de grupos marginalizados de áreas não urbanas e se tornam uma preocupação para a saúde pública. Tornam-se um problema para médicos sanitaristas e antropólogos que adentram o cenário das investigações relacionadas à saúde. Há então um distanciamento de vários pesquisadores em relação aos povos indígenas, inclusive dos historiadores. Ademais, nas décadas de 1970 e 1980, os estudos das sociedades a partir das estruturas continuam, porém, com o viés marxista, que foi a grande base teórica para vários programas de pesquisa. As investigações que abordavam etnicidade continuavam, contudo, sobre novos interesses, voltados para a área econômica. Os estudos sobre alimentação voltavam-se para as classes populares urbanas, suas culturas e ideologias. A História Econômica e a História da Cultura Material ganham força, influenciando diversos trabalhos sobre alimentação em que a cultura indígena não entrava. 
Dentre as abordagens contemporâneas, nas décadas de 1990 e 2000, começam a despontar nos estudos da alimentação questões ligadas aos alimentos locais, às cozinhas étnicas e aos movimentos gastronômicos. As pesquisas começam a buscar cada vez mais a formação das cozinhas invisibilizadas até então. Além disso, questionam o impacto da globalização tecnológica nas mudanças de hábitos alimentares e investigam os movimentos de resistência e identidades locais. De modo geral, tendem a minimizam o fator exótico do "outro" e o distanciamento criado pela perspectiva eurocêntrica para construir uma história em que há menor ênfase hierárquica entre conhecimentos. Dentro desse mesmo contexto de pesquisas, os livros de culinária passam a abordar mais do que ingredientes e modos de fazer. Permitem, também, análises que demonstrem a importância e ancestralidade da culinária e da profissão do cozinheiro e cozinheira nos dois últimos séculos.

Essas abordagens ficam mais evidentes, provavelmente, devido à ampliação da perspectiva da história cultural e da hermenêutica ou interpretação na antropologia cultural ${ }^{11}$. Essas perspectivas desenvolveram ideias que começaram a circular nas áreas social e política como o multiculturalismo e a interculturalidade crítica $^{12}$, evidentes nos âmbitos socioculturais na contemporaneidade. É a partir do final da década de 1990 que trabalhos como "A história da alimentação: baliza historiográfica" (1997), de Ulpiano Toledo Bezerra de Meneses e Henrique Soares Carneiro; "Comida e sociedade: uma história da alimentação" (2003) e "Comida e sociedade: significados sociais na História da alimentação" (2005), de Henrique Soares Carneiro; e "A alimentação e seu lugar na História: os tempos da memória gustativa" (2005), de Carlos Roberto Antunes dos Santos, são publicados. Os estudos apresentam a trajetória da construção da

11 Antropologia hermenêutica ou interpretativa, constitui uma perspectiva teórica da antropologia produzida por Clifford Geertz disseminada em sua obra A Interpretação das Culturas, publicada no ano de 1978. Foi compreendida por Michel Fischer (1985) assim como por outros antropólogos como Victor Turner, Terence Turner e David Schneider como uma das principais vertentes da antropologia contemporânea. Nesta perspectiva teórica, o pesquisador busca o significado das práticas sociais, dos símbolos, para compreensão do "outro" como ser social.

12 Interculturalidade crítica, de acordo com Catherine Walsh (2009), corresponde a uma perspectiva crítica que se encontra ligada com uma pedagogia e práxis orientadas ao questionamento, transformação, intervenção, ação e criação de condições radicalmente distintas de sociedades, humanidades, conhecimento e vida, que se encaminham para a decolonialidade. 
PEREIRA, T. M. G., MAGALHÃES, S. M. e NAZARENO E. Estado do Conhecimento sobre História...

História da alimentação sob o enfoque sociocultural. É provável que a perspectiva da história cultural tenha influenciado na construção desses textos, pois nota-se neles uma preocupação em fazer uma revisão sobre as publicações que tratam sobre os primeiros escritos sobre alimentação, os quais influenciaram a construção do nosso legado informacional sobre alimentação e identidade brasileira.

Outros trabalhos desse mesmo período sugerem temas que ainda estavam ocultos em trabalhos anteriores, como a revisão da formação da identidade e do patrimônio alimentar nacional e regional. Em 2004, a revista "Estudos Históricos", vinculada à Fundação Getúlio Vargas do Rio de Janeiro, lança o artigo "A fome e o paladar: a antropologia nativa de Luís da Câmara Cascudo", de José Reginaldo Santos Gonçalves, no qual são discutidas algumas categorias culinárias no contexto da cultura popular brasileira, representada por Luís da Câmara Cascudo, levantando problemas e hipóteses para compreensão do sistema culinário no Brasil. Em 2005, a revista Nossa História, da Fundação da Biblioteca Nacional do Rio de Janeiro, publica o artigo Delícias goianas, de Sônia Maria de Magalhães.

Na década de 2010, as preocupações se voltam à história do consumo alimentar, da globalização e saúde. São discutidas, como parte dos debates, a cultura do consumo e as preocupações com a saúde na atualidade. Há também estudos voltados ao legado deixado pelos autores do século passado. Observamos o que temos como patrimônio historiográfico voltado para a alimentação para lançar novas bases críticas e indagar as lacunas.

Não podemos deixar de mencionar, nesse contexto, o que Algranti e Asfora (2014) afirmaram a respeito da história da alimentação e das tradições alimentares. No artigo "Luís da Câmara Cascudo e a ementa portuguesa: a contribuição de Portugal na construção do pensamento sobre a cozinha brasileira", as autoras indicam que até meados do século XX a alimentação "não fazia parte da agenda principal de historiadores e cientistas sociais" (ALGRANTI; ASFORA, 2014, p. 254). Tratava-se de um tema médico e até então contava apenas com estudos esparsos, entre eles o de Gilberto Freyre sobre cozinha do nordeste brasileiro. Posteriormente, a perspectiva de Cascudo (1968) trará outra percepção a respeito da alimentação. De acordo com Algranti e Asfora (2014), enquanto Cascudo vê a alimentação como dinâmica, pois dialoga passado com o presente, Freyre vê a tradição como algo cristalizado, cujo propósito era perpetuar as estruturas herdadas. Para Freyre, a cozinha era quase um monumento a ser preservado. Para Cascudo, ao contrário, a cozinha estava viva. 
Apesar de as produções voltadas aos povos indígenas no âmbito da alimentação continuarem reduzidas, houve um aumento de trabalhos com enfoque nas mais diversas temáticas alimentares, ocorrendo mudanças na forma de olhar para esses povos. Várias dissertações sobre o tema foram defendidas em instituições universitárias diferentes das quais damos destaque à "A cultura alimentar Paulista: uma civilização do milho? (1650-1750)" (2012), defendida por Rafaela Basso. A historiadora desenvolveu uma importante pesquisa sobre a cultura alimentar paulista durante o período colonial brasileiro, mencionando o conflito documental entre evidências e silenciamentos quanto ao consumo de milho em São Paulo. Ela constata que haveria uma justaposição no abastecimento e no consumo deste e de outros produtos alimentares, tais como a mandioca, o feijão, o trigo, as carnes de víveres e outros, contrapondo à ideia inicial disseminada por Holanda (1945; 1956) sobre o exacerbado consumo de milho. A autora também afirma que haveria uma hierarquização do consumo, relacionado diretamente ao poder econômico dos colonos: o milho seria consumido em situações de mais escassez alimentar, enquanto a mandioca ou o trigo seriam preferidos, pois indicariam mais elaboração de produção e, portanto, seriam alimentos mais nobres e afastados da "primitividade" indígena. Neste trabalho, assim como em outros, o indígena passa a ser reincluído na história brasileira, porém problematizado como protagonista e agente dessa história.

\section{PUBLICAÇÕES SOBRE HISTÓRIA DA ALIMENTAÇÃO INDÍGENA NA ATUALIDADE}

Entre as publicações recentes a respeito da História da alimentação indígena no Brasil, destacamos mais alguns livros, dissertações e teses sobre o assunto que foram divulgados, sobretudo, a partir do ano 2000. Iniciando pelos livros, temos o título "Transformação e persistência: antropologia da alimentação e nutrição em uma sociedade indígena amazônica", escrito por Maurício Soares Leite. O livro foi publicado pela editora Fiocruz e é oriundo da tese de doutoramento do autor defendida no ano de 2004, pela mesma instituição. Nesse livro, ele descreve aspectos nutricionais e alimentares do 
povo Wari, conhecidos na literatura por Paakanóva, localizados no Estado de Rondônia. O autor busca compreender de maneira interdisciplinar (âmbitos da saúde, sociocultural, político e histórico) as condições de vida da população, pautadas nas formas que este povo tem de ver e de existir no mundo.

Outro título que podemos destacar é "Delícias do descobrimento: a gastronomia brasileira no século XVI" (2009), de Sheila Moura Hue, Angelo Augusto Santos e Ronaldo Menegaz. Nesse livro, os autores apresentam a história do Brasil pela gastronomia, citando diversos documentos escritos por missionários, viajantes e senhores de engenho, apresentando receitas vigentes desde o século XVI até os dias de hoje. O indígena é parte ativa da obtenção dos ingredientes, dos modos de fazer das receitas e dos medicamentos neste Novo Mundo.

Cinco anos mais tarde, o livro "Comida dos Nativos do Novo Mundo" (2014), escrito por Messias S. Cavalcante, descreve a fauna, a flora, os instrumentos, os modos de preparo e as formas de obtenção de alimentos pelos povos indígenas das Américas do Norte, Central e Sul. Recentemente, as autoras Maria Christina de Almeida Costa e Eunice Salzano Lago organizam o livro "Nelson Chaves - Alimentação e Sociedade: A inter-relação dos aspectos antropológicos, culturais e sociais com a nutrição" (2017), que reúne os escritos do professor Nelson Chaves sobre alimentação e cultura. Nesse livro, é destinado um longo capítulo a respeito da alimentação indígena e saúde, correlacionando a cultura, a sociedade e as escolhas alimentares.

As teses e dissertações que tratam sobre o tema da alimentação indígena são bastante recentes. Elas também começam a despontar a partir dos anos 2000, trabalhando, sob o olhar da Antropologia, as dimensões do simbólico, e sob o olhar da Nutrição, a dieta, a saúde indígena, e sob o olhar da História, os aspectos históricos sociais e mudanças no consumo alimentar.

A primeira dissertação sobre alimentação indígena foi defendida no ano 2005, tendo como título "Orerémbiú: a relação das práticas alimentares e seus significados com a identidade étnica e a cosmologia Mbya-Guarani”, escrita por Mártin César Tempass, no Programa de Pós-Graduação em Antropologia Social da Universidade Federal do Rio Grande do Sul (UFRGS). Essa dissertação tratou da temática da alimentação voltada para os indígenas e suas relações na contemporaneidade. Nela, o autor analisa as dimensões do comer e do simbólico, tendo a cosmologia um lugar de destaque nas interpretações das comunidades Guarani, no Rio Grande do Sul.

Em 2008, a dissertação "O mundo universal: alimentação e aproximações culturais no Novo Mundo ao longo do século XVI”, escrita por 
Rubens L. Panegassi, foi defendida no Programa de Pós-Graduação em História da Universidade de São Paulo. Nesta, o autor enfatiza o processo de colonização das Américas pelas nações Ibéricas, tendo como principais fontes os registros de caráter etnográfico, cartas e crônicas escritas no século XVI por viajantes que registraram a cultura alimentar dos "nativos". O autor buscou demonstrar como os alimentos se constituem em instrumentos mediadores de igualdades e diferenças culturais. Além disso, ele observou como esses alimentos permitiram ao europeu incorporar intelectualmente sua experiência nas Américas.

E entre as teses destacamos três, das quais uma foi defendida dentro da área de nutrição e as outras duas nas áreas de antropologia e ciências sociais. A primeira delas foi apresentada no ano de 2004, por Maurício Soares Leite, ao Programa de Pós-Graduação em Ciências da Saúde da Escola Nacional de Saúde Pública - FIOCRUZ. Teve por título "Iri' Karawa, Iri' Wari': um estudo sobre práticas alimentares e nutrição entre os índios Wari' (Paakanova) do sudoeste amazônico". Três anos mais tarde ela se tornaria o livro "Transformação e Persistência: antropologia da alimentação e nutrição em uma sociedade indígena amazônica", citado acima. Nesse trabalho, o autor busca ir além de dados quantitativos e das análises que utilizam os métodos do perfil nutricional, que muitas vezes não levam em consideração os múltiplos fatores que influenciam a alimentação. Maurício Leite busca, com o auxílio dos métodos e teorias da antropologia, nas dimensões ambientais, culturais, políticas e econômicas, os fatores que agem diretamente sobre as escolhas das práticas alimentares. Ele ainda traz relevância aos fatores da sazonalidade ecológica para discutir o estado nutricional e a forma como os indígenas tratam da sua saúde, segundo suas próprias concepções de mundo. Este último significou um ponto pouco explorado pela nutrição na época.

No ano seguinte, em 2005, a tese "Cativando Maira: a sobrevivência Avá-canoeiro no alto Rio Tocantins", escrita por Cristhian Teófilo da Silva, foi defendida no Programa de Pós-Graduação em Antropologia Social da Universidade de Brasília (UNB). Nesta, o autor buscou demonstrar as dificuldades extremas pelas quais passavam os Aváscanoeiros devido ao processo violento que quase resultou no etnocídio por completo desse povo. A alimentação não se apresenta em primeiro plano articulatório das ideias, porém aparece como um dos fatores de grande importância documentado pelo autor. 
Além destas, no ano de 2007, a tese "“A gente é como aranha...vive do que tece': Nutrição, saúde e Alimentação entre os índios Kiriri do sertão da Bahia" foi apresentada por Sandra Simone Queiroz de Moraes Pacheco ao Programa de Pós-Graduação em Ciências Sociais da Universidade Federal da Bahia (UFBA). Nela, a autora realiza a documentação e análise da ocupação indígena na área demarcada e a relação com a disponibilidade de alimento. Ela realiza também um estudo nutricional e simbólico a respeito dos usos dos alimentos presentes nas aldeias na contemporaneidade.

No ano de 2011, houve um aumento no número de teses e dissertações defendidas, havendo um total de sete trabalhos apresentados nas áreas de antropologia, ciências ambientais, desenvolvimento sustentável e desenvolvimento regional. Dentre estes, podemos destacar a dissertação “"Nossa cultura é pequi, frutinha do mato': um estudo sobre as práticas alimentares do povo Akwe", escrita por Rosana Schmidt, que foi apresentada ao Programa de Pós-Graduação em Antropologia Social da Universidade Federal de Goiás (UFG). No trabalho, as regras sociais do comer entre os povos Akwe/Xerente do estado do Tocantins são descritas e analisadas por meio de observações participantes, entrevistas e dados coletados pela pesquisadora. Um ano depois, a dissertação "Alimentação indígena em Mato Grosso: Educação ambiental e sustentabilidade entre etnias de estudantes da faculdade indígena intercultural", escrita por Gabrielle Baldo Crespaldi, foi defendida no Programa de Pós-Graduação em Ciências Ambientais da Universidade do Estado de Mato Grosso (UNEMAT). Em 2013, a dissertação "Segurança alimentar e etnodesenvolvimento na Terra Indígena Panambizinho" foi defendida por Ione Santos do Nascimento, no Programa de Pós-Graduação em Desenvolvimento Sustentável da Universidade de Brasília (UNB). No mesmo ano, a dissertação "Alimentos, restrição e Reciprocidades no ritual Xavante do Wapté mnhõno (Terra Indígena Marãiwatsédé, Mato Grosso)" foi defendida por Sayonara Maria Oliveira da Silva, no Programa de PósGraduação em Desenvolvimento Sustentável da Universidade de Brasília (UNB). Dois anos depois, em 2015, a dissertação "O PAA, Política Social e Povos Indígenas: um estudo de Caso do Programa de Aquisição de Alimentos no município de Ipuaçu - SC", escrita por Cristiane Golembieski, foi defendida no Programa de Pós-Graduação em Desenvolvimento Regional da Universidade Tecnológica Federal do Paraná (UTFPR).

Das teses que discutiram sobre a alimentação indígena a partir do ano de 2010, podemos citar duas. A primeira, sob o título "'Quanto mais 
doce melhor': Um estudo antropológico das práticas alimentares da doce sociedade Mbyá-Guarani”, foi apresentada em 2010 por Martín César Tempass ao Programa de Pós-Graduação em Antropologia da Universidade Federal do Rio Grande do Sul (UFRGS). Nesta, o autor descreve e discute a história do paladar doce entre os Mbyá-Guarani, os alimentos e sua origem doce, seus significados, trocas e usos na contemporaneidade. A outra tese, sob o título de "Feira Krahô de sementes tradicionais: cosmologia, história e ritual no contexto de um projeto de segurança alimentar", foi defendida por Júlio César Borges, no Programa de Pós-Graduação em Antropologia Social da Universidade de Brasília (UNB), em 2014, na qual menciona a importância e os significados das trocas de sementes alimentares e sua relação cosmológica Krahô.

Nota-se que houve um aumento considerável dos trabalhos relacionados aos povos indígenas durante esse período, que pode ser atribuído ao interesse pelo modo de vida e relações que esses povos possuem com o meio ambiente. Esses trabalhos apresentam as novas políticas ambientais, que buscam implementar a sustentabilidade no manejo ambiental diante os novos problemas ecológicos (crises hídricas e climáticas). Tendo as populações indígenas, durante milênios, praticado o manejo sustentável do território e consequentemente dos produtos existentes na alimentação, os olhares da academia se voltam para suas práticas, significados e interações com o ambiente. Em que pese todo o processo de apagamento empreendido pelo projeto colonizador, sobretudo aqueles vinculados à colonialidade do poder, do saber e do ser, pelo menos parte das epistemologias e formas de bem viver indígenas ainda permanecem vivas. Elas estão evidenciadas na existência contemporânea no Brasil de mais de 300 povos com aproximadamente 200 línguas indígenas.

\section{CONSIDERAÇÕES FINAIS}

O aumento significativo de publicações sobre a temática da alimentação, nas mais diversas áreas do conhecimento, indica o quanto ela começa a se fazer importante nas últimas décadas. A necessidade de 
PEREIRA, T. M. G., MAGALHÃES, S. M. e NAZARENO E. Estado do Conhecimento sobre História...

produção e de análises que proporcionassem pensar as ações humanas no âmbito do comer, as suas relações com o meio, com a saúde e com o consumo na contemporaneidade, foram chaves para que se alavancassem mais discussões.

Contudo, mesmo com o aumento de publicações, observou-se que as produções dentro da temática da História da Alimentação indígena ainda são baixas. Entre os trabalhos mais recentes na área de humanidades, observou-se a abertura das lentes de conhecimento e análises que abrangessem aspectos socioculturais, ecológicos, psíquicos e médicos de forma inter-relacional. $\mathrm{O}$ consumo, no contexto contemporâneo, torna-se tema central de muitas investigações sobre os alimentos e alimentação. Ao lado desse tema, estão as investigações que priorizam o papel da comida na construção ou desconstrução de identidades, os discursos sobre o saudável nutricional, as transformações ocorridas a partir das novas relações entre campo e cidade, o corpo, a estética e o bem-estar. Na grande maioria dos trabalhos, a busca por sentidos e significados orientam as investigações, que demonstram cada vez mais o papel da mídia na produção destes (FERREIRA et. al., 2013).

Ademais, as abordagens que se detém em análises etnográficas mencionam pouco os dados contextuais históricos. A perspectiva trazida pelas análises étnicas pós-coloniais, interculturais e decoloniais também são poucas. Porém, tendem a aumentar significativamente, uma vez que esta tem sido focada nas últimas décadas, principalmente nas discussões que apresentam as maneiras de pensar, agir e ser no contexto contemporâneo.

A construção do indígena, em muitos trabalhos, é realizada dentro de circunstâncias que indicam a presença de leis e direitos internacionais que defendem suas identidades, práticas e formas de pensar, porém a exclusão, espoliação e violência ainda acontece, executada pelo Estado, transnacionais, multinacionais e fazendeiros a favor da produção para o comércio nacional e internacional. Os efeitos dessas ações têm excitado cada vez mais a busca por reflexões e análise que sejam capazes de conhecer e expor essa realidade social e problematizá-la na história brasileira.

Castro-Goméz (2005), filósofo colombiano, nos convida a refletir sobre a genealogia da nossa herança colonial na América Latina e também no Brasil. Ele, assim como outros pesquisadores (Dussel, 1992; Mignolo, 2000; Quijano, 1999) afirmam de que maneira a modernidade construiu e gerou a alteridade, tentando excluir a diversidade, a multiplicidade de saberes e a vida concreta. $\mathrm{O}$ período gerou um sistema de poder que funciona a partir de uma lógica binária e, por conseguinte, exclui o que é diferente. No caso da América, 
a alteridade, o outro, esteve diretamente relacionada com o ser indígena. $\mathrm{O}$ autor, enumera, descreve e reflete sobre uma série de fatores que ocasionaram esse contexto, como as constituições nacionais, os manuais de boas maneiras e as gramáticas normativas dos idiomas que buscaram homogeneizar os indivíduos para tornar mais viável a governabilidade sobre eles.

Os manuais de boas maneiras transformaram-se nas novas "bíblias" dos indivíduos, regulando os comportamentos e construindo a obediência às normas de civilidade, como afirmou Elias, em "O processo civilizatório" (1990). O indivíduo ou cidadão deveria saber como falar, como escarrar ou limpar o nariz, como comer usando talheres e como se comportar à mesa. Tudo o que fugia disto seria excluído ou tratado como bárbaro. Desta maneira, separar o que é bárbaro e o que é civilizado, quem é bom e quem é mau, quem é racional e quem é irracional, quem é colonizador e quem é colonizado envolvia inicialmente os povos indígenas nas Américas e posteriormente os africanos (CASTRO-GOMÉZ, 2005).

Essa trajetória histórica também indica que houve a construção de um referencial de estágios de aperfeiçoamento social. As sociedades indígenas que estavam no estágio mais "primitivo" deveriam ser civilizadas para a alcançar o conhecimento das artes, escrita e ciência. Elas eram o outro absoluto das sociedades europeias, a outra raça. Obrigadas a terem aulas de religião, português, vestirem-se como europeus e comerem como não indígenas. Os povos indígenas foram influenciados pelos modos europeus, mas também muito influenciaram seus hábitos. Diferentemente das relações dos povos africanos, os indígenas teceram a trajetória de convivência colonial e pós-colonial de modo diferente. Não queremos nos delongar nessa questão, pois seria tema para outras investigações, mas consideramos importante chamar atenção para sua diferença de trajetória histórica.

Os trabalhos que enfocaram a alimentação indígena buscaram atribuir-lhes uma atuação significativa, desocultando e questionando as suas ações, buscando também um cunho político de denuncia social, tendo em vista a tentativa de contar uma outra história. Como caminhos para novas pesquisas, sugerimos trabalhos que envolvam, para além de documentos oficiais, as vozes indígenas, pautados em publicações feitas pelos acadêmicos e por não acadêmicos indígenas, e, ainda, a compreensão das práticas e da trajetória da alimentação indígena de modo que as particularidades dos povos sejam respeitadas. Propomos que haja a aproximação dos historiadores com 
PEREIRA, T. M. G., MAGALHÃES, S. M. e NAZARENO E. Estado do Conhecimento sobre História...

os povos indígenas para ampliação de conhecimento e eliminação de barreiras teóricas e epistêmicas.

\section{REFERENCIAS}

ABREU, Capistrano. Capítulos de História Colonial. Rio de Janeiro: M. Orosco \& C., 1907.

ALGRANTI, Leila Mezan; ASFORA, Wanessa. Luís da Câmara Cascudo e a ementa portuguesa: a contribuição de Portugal na construção do pensamento sobre a cozinha brasileira. In: SOARES, Carmen; MACEDO, Irene Coutinho (Org.). Ensaios sobre património alimentar luso-brasileiro. Coimbra: Imprensa da Universidade de Coimbra/ Coimbra University Press, 2014, p. 253-326.

ARON, Jean-Paul. A cozinha: um cardápio do século XIX. In: LE GOFF, Jacques; NORA, Jean-Paul. História: novos objetos. $1^{a}$ ed. Rio de Janeiro: Francisco Alves, 1976, p. 160-185.

BAHLOU, Joëlle. Nourritures de l'altérité: le double langage des Juifs algériens en France. Annales: Économies, Sociétés, Civilisations, ano 38, n. 2, 1983, p. 325-340.

BASSO, Rafaela. A cultura alimentar Paulista: uma civilização do milho? (16501750). Dissertação (Mestrado em História) - Universidade Estadual de Campinas (UNICAMP), Campinas, 2012.

BORGES, Júlio César. Feira Krahô de sementes tradicionais: cosmologia, história e ritual no contexto de um projeto de segurança alimentar. Tese (Doutorado em Antropologia Social) - Universidade de Brasília. Brasília, 2014.

BRANDÃO, Carlos Rodrigues. Plantar, colher, comer: um estudo sobre o campesinato goiano. Rio de Janeiro: Edições Graal, 1981.

BRAUDEL, Fernand. O mediterrâneo e o mundo mediterrânico na época de Felipe II. São. Paulo: Martins Fontes, 1984.

Civilização material, economia e capitalismo: Séculos XV - XVIII. Editora Martins Fontes. São Paulo, 1995. 
BURKE, Peter. Abertura: A Nova História, seu Passado e seu Futuro. In: BURKE, Peter. (Org.). A escrita da História: Novas Perspectivas. Tradução de Magda Lopes. São Paulo: Editora UNESP, 1992, p. 7-37.

CANDIDO, Antonio. Os parceiros do Rio Bonito: Estudo sobre o caipira paulista e a transformação dos seus meios de vida. 11 ${ }^{\mathrm{a}}$ ed. Rio de Janeiro: Ouro sobre Azul, 2010.

CANESQUI, Ana Maria; GARCIA, Rosa Wanda Diez (Org.). Antropologia e Nutrição: um diálogo possível. Rio de Janeiro: Editora FIOCRUZ, 2005.

CARNEIRO, Henrique. Comida e sociedade: uma história da alimentação. $7^{\mathrm{a}}$ edição. Rio de Janeiro: Campus, 2003.

Campus, 2005.

Enciclopédia da história das drogas e bebidas. São Paulo: Editorial

CASCUDO, Luís da Câmara (Org.). Antologia da alimentação no Brasil. Rio de Janeiro: Livros Técnicos e Científicos Editora S.A., 1977.

2004.

. História da alimentação no Brasil. $3^{\mathrm{a}}$ ed. São Paulo: Editora Global,

CASTRO, Josué de. Geografia da fome: a fome no Brasil. Rio de Janeiro: Edições Antares, 1984 (1 $1^{\mathrm{a}}$ ed. 1946).

CASTRO-GÒMEZ, Santiago. A hybris do ponto zero: ciência, razão e ilustração na Nova Granada (1750-1816). Bogotá: Editorial Pontifícia Universidade Javeriana, 2005 .

CAVAlCANTE, Messias S. Comida dos Nativos do Novo Mundo. Barueri: Sá Editora, 2014.

CRESPALDI, Gabrielle Baldo. Alimentação indígena em Mato-Grosso: Educação ambiental e sustentabilidade entre etnias de estudantes da faculdade indígena intercultural. Dissertação (Mestrado em Ciências Ambientais) - Universidade do Estado de Mato Grosso. Cuiabá, 2012.

COSTA, Maria Christina e Almeida; LAGO, Eunice Salzano (Org.). Nelson Chaves Alimentação e sociedade: A inter-relação dos aspectos antropológicos, culturais e sociais com a nutrição. Recife: Cepe Editora, 2017.

DUSSEL, Enrique. 1492: El encubrimiento del otro. El orígen del mito de la modernidade. Bogotá: Edição Antropos, 1992. 
PEREIRA, T. M. G., MAGALHÃES, S. M. e NAZARENO E. Estado do Conhecimento sobre História...

ELIAS, Norbert. O Processo Civilizador. vol. 1. Uma História dos Costumes. Rio de Janeiro, Jorge Zahar Editores, 1990.

FERREIRA, Francisco Romão; FREITAS, Ricardo Ferreira; PRADO, Shirley Donizete; CARVALHO, Maria Claudia da Veiga Soares. O sabor da primeira coletânea: consumo, alimentação e cultura. In: FERREIRA, Francisco Romão; FREITAS, Ricardo Ferreira; PRADO, Shirley Donizete; CARVALHO, Maria Claudia da Veiga Soares (Org.). Alimentação, consumo e cultura, v. 1, $1^{\mathrm{a}}$ ed., Curitiba, CRV, 2013, p. 9-11.

FERREIRA, Norma Sandra de Almeida. As pesquisas denominadas "estado da arte". Educação \& Sociedade, ano XXIII, n. 79, agosto 2002.

FLANDRIN, Jean-Louis. Introdução. In: FLANDRIN, Jean-Louis; MONTANARI, Massimo. História da Alimentação. Tradução de Luciano Vieira Machado e

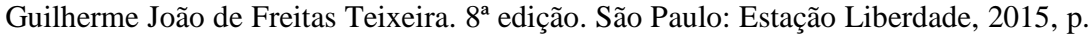
15-35.

FRANCO, Areovaldo. De caçador a gourmet: uma história da gastronomia. Brasília: Thesaurus, 1995.

FREIRE, José Ribamar Bessa. Da língua geral ao português: para uma história dos usos sociais das línguas na Amazônia. Tese (Doutorado em Letras) - Universidade Estadual do Rio de Janeiro. Rio de Janeiro, 2003.

FREYRE, Gilberto. Casa Grande e Senzala: Formação da família brasileira sob o regime da economia patriarcal. São Paulo: Global, 2003.

GOLEMBIESKI, Cristiane. O PAA, Política Social e Povos Indígenas: um estudo de Caso do Programa de Aquisição de Alimentos no município de Ipuaçu - SC. Dissertação (Mestrado em Desenvolvimento Regional) - Universidade Tecnológica Federal do Paraná. Paraná, 2015.

GOODY, Jack. Cozinhando: cozinha e classe. Cambridge: Cambridge University Press, 1982.

GONÇALVES, J. R. dos Santos. A fome e o paladar: a antropologia nativa de Luís da Câmara Cascudo. Revista Estudos Históricos, v. 1, n. 33, 2004, p. 40-55.

HISTÓRIA DA ALIMENTAÇÃO. Grupo de estudos sobre História, cultura e sociedade. Disponível em: < http://www.historiadaalimentacao.ufpr.br/>. Acesso em: maio 2016.

HOLANDA, Sérgio Buarque de. Caminhos e Fronteiras. 3.ed. São Paulo: Companhia das letras, 1994. 
Monções. $4^{\mathrm{a}}$ ed. São Paulo: Companhia das letras, 2014.

HUE, Sheila Moura. Delícias do descobrimento. Rio de Janeiro: Jorge Zahar Editor, 2008.

KATZ, Esther. Alimentação indígena na América Latina: comida invisível, comida de pobres ou patrimônio culinário? $26^{a}$ Reunião Brasileira de Antropologia, junho, Porto Seguro, 2013. Disponível em: https://seer.ufrgs.br/EspacoAmerindio/article/view/8319>. Acesso em: abr. de 2017.

LAGORIO, Consuelo Alfaro; FREIRE, José R. Bessa. Ayron Rodrigues e as Línguas Gerais na historiografia linguística. D.E.L.T.A., 30 ESPECIAL, 2014, p. 571-589.

LE GOFF, Jacques. A história nova. In: LE GOFF, Jacques; CHARTIER, Roger; REVEL, Jacques (Org.). A história nova. Tradução de Eduardo Brandão. $4^{\mathrm{a}}$ edição. São Paulo: Martins Fontes, 1998, p. 25- 64.

LÉVI-STRAUSS, Claude. Culinary Triangle. In: COUNIHAN, Carole \& VAN ESTERIK, Penny (Org.) Food and culture. New York: Routledge, 1997, p.28-35.

LEITE, Maurício Soares. Iri' Karawa, Iri' Wari': um estudo sobre práticas alimentares e nutrição entre os índios Wari' (Paakanova) do sudoeste amazônico. Tese (Doutorado em Ciências da Saúde) - Escola Nacional de Saúde Pública - FIOCRUZ. Rio de Janeiro, 2004.

- Introdução: Perspectivas Bioculturais em Alimentação e Nutrição. Transformação e Persistência: antropologia da alimentação e nutrição em uma sociedade indígena amazônica. Rio de Janeiro: Editora Fiocruz, 2007, p. 21-32.

MAURIZZIO, Adam. Histoire de l'alimentation végétale chez l'Homme. Revue de botanique appliquée et d'agriculture coloniale, ano 11 , boletim $\mathrm{n}^{\circ} 115$, mar. 1931, $\mathrm{p}$. 159-168.

MAGALHÃES, Sônia Maria de. Alimentação, saúde e doença em Goiás no século XIX. Tese (Doutorado em História) - Universidade Estadual Paulista. Franca, 2004.

. Delícias goianas. Revista Nossa História, v. 18, n.18, p. 38-40, 2005.

. A mesa de Mariana: Produção e consumo de alimentos em Minas Gerais (1750-1850). Goiânia: Editora da Imprensa Universitária, 2018.

MEAD, Margaret. A cultura cambiante de uma tribo índia. Nova Iorque: Capricorn Books, 1932. 
PEREIRA, T. M. G., MAGALHÃES, S. M. e NAZARENO E. Estado do Conhecimento sobre História...

. Sexo e temperamento em três sociedades primitivas. Nova Iorque:

George Routledge, 1935.

MENESES, Ulpiano T. Bezerra; CARNEIRO, Henrique. A história da Alimentação: balizas historiográficas. Anais do Museu Paulista, v. 5, n. 1, 1997.

MENNEL, Stephen. Introdução. Todas as maneiras de comer. Ilinois: Universidade de Ilinois Press, 1996.

Universidade de Ilinois, 1996.

MIGNOLO, Walter. Local Histories / Global Designs. Coloniality, Subaltern Knowledges and Border Thinking. Princeton: Princeton University Press, 2000.

MINTZ, Sidney. Comida, sociabilidade e açúcar. Doçura e poder: o lugar do açúcar na história moderna. Nova Iorque: Penguin Books, 1985.

. Comida e antropologia: uma breve revisão. In: RBCS, vol. 16, n. 47, outubro/2001. Disponível em: <HTTP://www.scielo.br/pdf/rbcsoc/v16n47/7718.pdf>. Acesso em: junho de 2014.

Açúcar e Moralidade. Sabor a comida, sabor a liberdade. México:

Ediciones La Reina Roja, 2003.

NASCIMENTO, Ione Santos do. Segurança alimentar e etnodesenvolvimento na

Terra Indígena Panambizinho. Dissertação (Mestrado em Desenvolvimento Sustentável) - Universidade de Brasília. Brasília, 2013.

NAZARENO, Elias. El bilingüismo em la construcción de la nación brasileña. In: LUQUE, Molina Fidel (Ed.). Alternativas em educación intercultural. El caso de América Latina: la educación intercultural y bilíngue. Lleida: de París edições, 2008.

O Estado e as políticas linguísticas adotadas como estratégicas na formação da nação brasileira a partir do século XVI. In: XAVIER, Lídia de Oliveira; AVILA, Carlos F. Domínguez; FONSECA, Vicente (Org.). A qualidade da democracia no Brasil: questões teóricas e metodológicas da pesquisa. 4 ed. Curitiba: CRV, 2019, v. 4, p. 299-317.

PACHECO, Sandra Simone Queiroz de Moraes. "A gente é como aranha...vive do que tece”: Nutrição, saúde e Alimentação entre os índios Kiriri do sertão da Bahia. Dissertação (Mestrado em Ciências Sociais) - Universidade Federal da Bahia. Salvador, 2007. 
PANEGASSI, Rubens Leonardo. $O$ mundo universal: alimentação e aproximações culturais no Novo Mundo ao longo do século XVI. Dissertação (Mestrado em História) - Universidade de São Paulo. São Paulo, 2008.

PEZZODIPANE, Rosane Vieira. Pós-colonial: a ruptura com a história única. Revista Simbiótica, UFES, v. único, n. 3, p.87-97, jun., 2013.

PIN, André E. História da educação do povo Javaé: do período colonial à República. Dissertação (Mestrado em História) - Universidade Federal de Goiás. Goiânia, 2014.

QUIJANO, Aníbal. Colonialidade del poder, cultura e conocimento em America Latina. In: CASTRO-GÓMEZ, S.; GUARDIOLA-RIVERA, O.; MILLÁN DE BENAVIDES, C. (Ed.). Pensar (en) los interticios. Teoría y práctica de la crítica pós-colonial. Bogotá: CEJA, 1999.

SANTOS, Carlos Roberto Antunes dos. A alimentação e seu lugar na história: os tempos da memória gustativa. História: Questões \& Debates, Curitiba, v. 42, p. 11$31,2005$.

SCHMIDT, Rosana. "Nossa cultura é pequi, frutinha do mato": um estudo sobre as práticas alimentares do povo Akwe. Dissertação (Mestrado em Antropologia Social) Universidade Federal de Goiás. Goiânia, 2011.

SILVA, Cristhian Teófilo da. Cativando Maira: a sobrevivência Avá-canoeiro no alto Rio Tocantins. Tese (Doutorado em Antropologia Social) - Universidade de Brasília. Brasília, 2005.

SILVA, Sayonara Maria Oliveira da. Alimentos, restrição e Reciprocidades no ritual Xavante do Wapté mnhõno (Terra Indigena Marãiwatsédé, Mato Grosso). Dissertação (Mestrado em Desenvolvimento Sustentável) - Universidade de Brasília. Brasília, 2013 .

SLONGO, Iône Inês Pinsson. A produção acadêmica em ensino de biologia: um estudo a partir de teses e dissertações. Tese (Doutorado em Educação) - Universidade Federal de Santa Catarina. Florianópolis, 2004.

SHARPE, Jim. A história vista de baixo. In: BURKE, Peter (Org.). A escrita da História: novas perspectivas. São Paulo: Editora da Universidade Estadual Paulista, 1992, p. 39-62.

SOUSA, Gabriel Soares de. Tratado Descritivo do Brasil em 1587. Disponível em: <http://www.dominiopublico.gov.br/download/texto/me003015.pdf>. Acesso em: maio de 2016. 
PEREIRA, T. M. G., MAGALHÃES, S. M. e NAZARENO E. Estado do Conhecimento sobre História...

TEMPASS, Mártin César. Orerémbiú: a relação das práticas alimentares e seus significados com a identidade étnica e a cosmologia Mbya-Guarani. Dissertação (Mestrado em Antropologia Social) - Universidade Federal do Rio Grande do Sul. Porto Alegre, 2005.

. "Quanto mais doce melhor”: Um estudo antropológico das práticas alimentares da doce sociedade Mbyá-Guarani. Tese (Doutorado em Antropologia) Universidade Federal do Rio Grande do Sul. Porto Alegre, 2010.

WALSH, Catherine. Interculturalidade crítica e pedagogia decolonial: in-surgir, reexistir e re-viver. In: CANDAU, Vera Maria (Org.). Educação Intercultural na América Latina: entre concepções, tensões e propostas. Rio de Janeiro: 7 letras, 2009, p. 12-42.

RECEBIDO EM: 07/12/2018. APROVADO EM: 20/08/2019. 